\title{
Geostatistics applied to the environmental mapping of aviaries
}

\author{
Iug Lopes ${ }^{1,2}$, Marcos V. da Silva², Juliana M. M. de Melo $^{2}$, Abelardo A. de A. Montenegro² \& \\ Héliton Pandorfi ${ }^{2}$ \\ ${ }^{1}$ Instituto Federal de Educação, Ciência e Tecnologia Baiano/Departamento de Agronomia, Bom Jesus da Lapa, BA, Brasil. E-mail: iuglopes@hotmail.com \\ (Corresponding author) - ORCID: 0000-0003-0592-4774 \\ ${ }^{2}$ Universidade Federal Rural de Pernambuco/Departamento de Engenharia Agrícola, Recife, PE, Brasil. E-mail: marcolino_114@hotmail.com - \\ ORCID: 0000-0002-1318-2320; medrado.juliana@gmail.com - ORCID: 0000-0003-2554-2423; montenegro.ufrpe@gmail.com - 0000-0002-5746-8574; \\ hpandorf@hotmail.com - ORCID: 0000-0002-2037-8639
}

\begin{abstract}
Spatial variability analysis of meteorological elements and precise identification of possible causes of thermal stress in poultry housing help producers in the decision making process. The objective of this study was to evaluate the internal environment of poultry houses in the downtime (sanitary void) and in the production phase, to characterize spatial thermal variability and to identify critical control points. The study was carried out in the Alluvial Valley of the Mimoso River, municipality of Pesqueira, PE, Brazil. The data of air temperature, wind speed and illuminance were recorded in November (spring season), at 155 points within each poultry facility $(10 \times 90 \mathrm{~m})$, spaced in a $3.0 \times 2.5 \mathrm{~m}$ grid and subjected to descriptive statistical analysis and geostatistics. There was a strong spatial dependence for the variables air temperature, wind speed and illuminance. The ranges obtained for the air temperature in the facilities were from 48.22 to $114.52 \mathrm{~m}$, while for the wind speed and illuminance were less than $10 \mathrm{~m}$, thus revealing the need for greater homogeneity of the studied variables and meeting of the thermal requirement of the poultry.
\end{abstract}

Key words: ambience, thermal comfort, poultry production, downtime

\section{Geoestatística aplicada ao mapeamento ambiental de galpões avícolas}

RESUMO: A análise da variabilidade espacial dos elementos meteorológicos e identificação precisa de possíveis causas de estresse térmico no alojamento das aves, auxiliam os produtores no processo de tomada de decisão. Objetivou-se com este estudo avaliar o ambiente interno de aviários no vazio sanitário e na fase de produção, para caracterização da variabilidade térmica espacial e identificação de pontos críticos de controle. O estudo foi realizado no Vale Aluvial do Rio Mimoso, município de Pesqueira, PE, Brasil. Os dados de temperatura do ar, velocidade do vento e iluminância foram registrados no mês de novembro (primavera), em 155 pontos dentro de cada instalação avícola $(10 \times 90 \mathrm{~m})$, espaçados por malha de 3,0 × 2,5 m e submetidos a análise estatística descritiva e geoestatística. Ocorreu forte dependência espacial para as variáveis temperatura do ar, velocidade do vento e iluminância. Os alcances obtidos para a temperatura do ar nas instalações foram de 48,22 a $114,52 \mathrm{~m}$, enquanto que para a velocidade do vento e a iluminância foram menores que $10 \mathrm{~m}$, revelando assim, a necessidade de maior homogeneidade das variáveis estudadas e atendimento da exigência térmica das aves.

Palavras-chave: ambiência, conforto térmico, produção avícola, vazio sanitário 


\section{INTRODUCTION}

Micrometeorological monitoring of aviaries requires specific instrumentation, dedicated to recording air temperature, air relative humidity, wind speed and black globe temperature, as a minimum requirement for thermal characterization of the built environment. Thus, conventional instrumentation has been complemented with data-loggers, devices that enable the automatic recording of data, as well as their storage and database formation, expanding the sampling capacity for analysis and precise guiding for decision-making processes (Yang et al., 2012; Wang et al., 2016).

The greater availability of temporal and regionalized data of the interior of the facilities enables an analysis of the spatial variability of meteorological elements and precise identification of possible causes of thermal stress in the housing of birds, through geostatistics (Queiroz et al., 2017). Faria et al. (2008) highlighted that knowing the spatial variability of the microclimate in sheds is an indispensable factor in seeking the homogeneity, well-being and productivity of the confined animals.

The use of geostatistics, as well as the generation of maps, makes the interpretation of the environment more precise, enabling an adequate visualization of critical points that can be controlled (Carvalho et al., 2011; Medeiros et al., 2014; Queiroz et al., 2017).

Thus, this study was conducted to evaluate the internal environment of aviaries in the downtime (aviary 1) and in the production phase (aviary 2), for the characterization of the spatial thermal variability, identification of critical control points and analysis of uncertainties in estimates and generation of maps.

\section{Material ANd Methods}

The study was carried out in the Alluvial Valley of the Mimoso River in the municipality of Pesqueira, PE, Brazil ( $8^{\circ} 23^{\prime} 32^{\prime \prime} \mathrm{S}$; $36^{\circ} 51^{\prime} 78^{\prime \prime} \mathrm{W}$; altitude of $604 \mathrm{~m}$ ). According to Köppen-Geiger, the climate of the region is classified as BSsh - hot semi-arid (steppe) climate, with average annual precipitation of $730 \mathrm{~mm}$.

The data were recorded in medium-sized production units, in the downtime - sanitary void (aviary 1) and in the production phase (aviary 2) (Figure 1A). Data collection was carried out in the spring (November 21 to 22, 2017), which has the highest values of air temperature and the most critical condition for the control of environmental variables in the semi-arid region. Figures $1 \mathrm{C}$ and $\mathrm{D}$ show the values of minimum, mean and maximum temperatures, air relative humidity and precipitation obtained at the station throughout the year 2017 to characterize the local condition.

The two aviaries are $90.0 \mathrm{~m}$ long and $10.0 \mathrm{~m}$ wide, with ceiling height of $2.5 \mathrm{~m}$ and orientation according to Figure $1 \mathrm{~A}$. The lateral closure consisted of 0.10-m-high masonry walls and $0.05 \times 0.05 \mathrm{~m}$ plastic mesh, associated with blue polypropylene curtain. The floor was made of concrete and the pillars were made of precast concrete with $0.20 \times 0.20 \mathrm{~m}$, spaced apart by $3.0 \mathrm{~m}$. The roof was double pitched, with wooden structure and covered by Roman-type ceramic tiles.

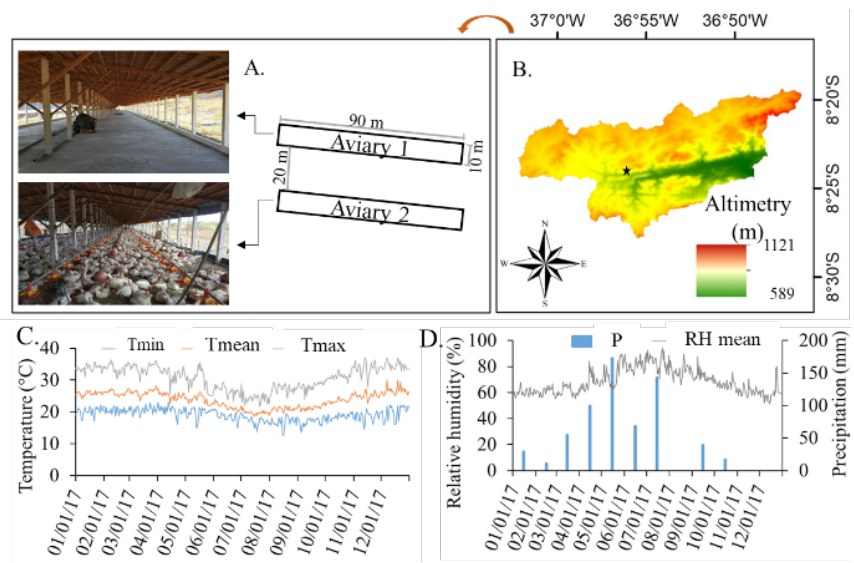

Tmin, Tmean, Tmax - Minimum, mean and maximum temperatures, respectively

Figure 1. Internal view of the aviaries in the phases of downtime - sanitary void and production (A), geographical location (B), daily variation outside the environment of air temperature $(\mathrm{C})$, air relative humidity - $\mathrm{RH}$ and precipitation - P (D) in 2017

In aviary 1 there was no type of cooling system, nor the presence of birds, being considered as a control of the environmental condition. Aviary 2, in production, had an adiabatic evaporative cooling system (30 min alternation between on and off), composed of 10 typhoon-type axial fans (total flow rate of $30 \mathrm{~m}^{3} \mathrm{~s}^{-1}$ ) and 10 nebulizers with flow rate of $6 \mathrm{~L} \mathrm{~h}^{-1}$ (high-pressure nebulization - 4.0 MPa), which allowed the housing of 11,700 birds, Cobb strain (13 birds $\left.\mathrm{m}^{-2}\right)$. The birds were in the last week of the production cycle (40 days).

Air temperature $\left({ }^{\circ} \mathrm{C}\right)$, wind velocity $\left(\mathrm{m} \mathrm{s}^{-1}\right)$ and illuminance (lux) data were obtained in November (spring season) at 9, 12 and $15 \mathrm{~h}$ and at 155 points in each aviary, spaced by a $3.0 \times 2.5 \mathrm{~m}$ grid.

Measurements were performed at a $0.5 \mathrm{~m}$ height from the floor at each point of the grid. The records were made simultaneously in the two aviaries, so there was no compensation between the two. Air temperature and wind speed data were recorded using a portable thermo-anemometer, with temperature reading range from -15 to $50{ }^{\circ} \mathrm{C}$ and wind speed from 0 to $30 \mathrm{~m} \mathrm{~s}^{-1}$. Illuminance data were recorded by a luxmeter with measuring capacity from 0 to 100,000 lux.

The temporal variability of the data was subjected to descriptive statistical analysis to obtain the mean, median and coefficient of variation $(\mathrm{CV})$, classified as low when $\mathrm{CV}$ $<12 \%$; medium when $12 \%<\mathrm{CV}<24 \%$ and high when $\mathrm{CV}$ $>24 \%$ (Warrick \& Nielsen, 1980). The Kolmogorov-Smirnov normality test was also applied at $\mathrm{p} \leq 0.01$.

Geostatistical analysis was performed based on the calculation of classical semivariances using Eq. 1, which estimates the structure and spatial dependence between the pairs of observations.

$$
\gamma(h)=\frac{1}{2 N(h)} \sum_{i=1}^{N(h)}\left[Z\left(x_{i}\right)-Z\left(x_{i}+h\right)\right]^{2}
$$

where:

$\gamma(\mathrm{h})$ - experimental semivariance, obtained by the sampled values $\mathrm{Z}\left(\mathrm{x}_{\mathrm{i}}\right), \mathrm{Z}\left(\mathrm{x}_{\mathrm{i}}+\mathrm{h}\right)$;

$\mathrm{N}(\mathrm{h})$ - number of pairs of measured values; 
$\mathrm{h}$ - distance between sample pairs; and,

$\mathrm{Z}\left(\mathrm{x}_{\mathrm{i}}\right)$ and $\mathrm{Z}\left(\mathrm{x}_{\mathrm{i}}+\mathrm{h}\right)$ - values of the $\mathrm{i}$-th observation of the regionalized variable, collected at the points $x i$ and $x_{i}+h(i=1$, ..., n), separated by the vector $h$.

Spatial dependence was analyzed by fitting the semivariogram based on the estimation of semivariance using the GEO-EAS ${ }^{\circ}$ program (Englund \& Sparks, 1989). Spherical, exponential and Gaussian models (Eqs. 2, 3 and 4, respectively) were fitted to the data, according to Deutsch et al. (1998).

Spherical model

$$
\gamma(h)= \begin{cases}\mathrm{C}\left[1.5 \frac{\mathrm{h}}{\mathrm{a}}-0.5\left(\frac{\mathrm{h}}{\mathrm{a}}\right)^{3}\right] & \text { if } \quad \mathrm{h} \leq \mathrm{a} \\ \mathrm{C} & \text { if } \mathrm{h} \geq \mathrm{a}\end{cases}
$$

Exponential model

$$
\gamma(h)=C\left[1-\exp \left(-\frac{3 h}{a}\right)\right]
$$

Gaussian model

$$
\gamma(h)=C\left[1-\exp \left(-\frac{(3 h)^{2}}{a^{2}}\right)\right]
$$

where:

$$
\begin{array}{ll}
\gamma(\mathrm{h}) & \text { - experimental semivariance; } \\
\mathrm{C} & \text { - sill; } \\
\mathrm{h} & \text { - distance between sample pairs; and, } \\
\mathrm{a} & \text { - range. }
\end{array}
$$

The fitted semivariograms were validated by the JackKnifing technique, where the mean should be close to zero and standard deviation close to 1 (Vauclin et al., 1983). The degree of spatial dependence (DSD) was classified according to Cambardella et al. (1994), which suggests strong dependence (St) < 25\%; moderate dependence (Md) between 25 and 75\%; and weak dependence (Wk) $>75 \%$.

Surfer 9 program (Golden Software, 2010) was used to construct the maps.

\section{RESUlts AND Discussion}

The values of air temperature in the morning ( $9 \mathrm{~h})$ were lower in the aviaries when compared to the times of 12 and $15 \mathrm{~h}$ (Table 1), since in the early morning the availability of direct solar radiation is lower and the wind speed higher, which promoted the reduction in air temperature, and the average daily air temperatures of the external environment were minimum of 19.38 , mean of 27.26 and maximum of $36.87^{\circ} \mathrm{C}$.

The daily air temperature in both facilities for the entire day showed a low CV (aviary 1: 0.60, 0.76 and 0.94; aviary 2: 1.95, 0.66 and $1.05 \%$ ), according to the methodology proposed by Warrick \& Nielsen (1980). Thus, it is observed that the air temperature had low longitudinal variation in the installation, considering that aviary 2 had an adiabatic evaporative cooling system. Gonçalves et al. (2016), studied the spatialization of physical variables of the air in rural construction and also observed a low $\mathrm{CV}$ for air temperature under semiarid conditions.

The CV values for wind speed in both facilities were high for all situations (Table 1). Similar variation was reported by Curi et al. (2014), who found high CV for wind speed when evaluating environmental control of the ventilation system of Blue House, Dark House and Solid Wall aviaries. This

\begin{tabular}{|c|c|c|c|c|c|c|c|c|c|}
\hline Variable & Mean & Median & ${ }^{7} \operatorname{Min}$ & ${ }^{8} \operatorname{Max}$ & ${ }^{9} \mathrm{SD}$ & ${ }^{10} \mathrm{CV}(\%)$ & ${ }^{11}$ Sk & ${ }^{12} \mathrm{Kt}$ & ${ }^{13} \mathrm{KS}$ \\
\hline \multicolumn{10}{|c|}{ Temperature $\left({ }^{\circ} \mathrm{C}\right)$} \\
\hline${ }^{1} \mathrm{~T}_{1}(9 \mathrm{~h})$ & 28.96 & 29.00 & 28.60 & 29.40 & 0.17 & 0.60 & 0.15 & 0.01 & $0.10^{* *}$ \\
\hline${ }^{2} \mathrm{~T}_{2}(9 \mathrm{~h})$ & 27.89 & 28.10 & 26.40 & 28.70 & 0.54 & 1.95 & -0.52 & -0.99 & $0.17^{\star \star}$ \\
\hline${ }^{1} \mathrm{~T}_{1}(12 \mathrm{~h})$ & 34.31 & 34.20 & 33.80 & 34.90 & 0.26 & 0.76 & 0.60 & -0.67 & 0.20 ** \\
\hline${ }^{2} \mathrm{~T}_{2}(12 \mathrm{~h})$ & 33.76 & 33.70 & 33.50 & 34.30 & 0.22 & 0.66 & 0.82 & -0.52 & 0.21 ** \\
\hline${ }^{1} \mathrm{~T}_{1}(15 \mathrm{~h})$ & 32.10 & 32.00 & 31.40 & 32.90 & 0.30 & 0.94 & 0.44 & -0.26 & $0.13^{\star \star}$ \\
\hline${ }^{2} \mathrm{~T}_{2}(15 \mathrm{~h})$ & 31.03 & 31.00 & 30.10 & 32.00 & 0.33 & 1.05 & 0.42 & 0.10 & $0.13^{* *}$ \\
\hline \multicolumn{10}{|c|}{ Wind speed $\left(\mathrm{m} \mathrm{s}^{-1}\right)$} \\
\hline${ }^{3} W_{1}(9 h)$ & 2.20 & 2.10 & 0.80 & 3.80 & 0.62 & 28.23 & 0.05 & -0.62 & $0.07 * *$ \\
\hline${ }^{4} W_{2}(9 h)$ & 1.44 & 1.47 & 0.56 & 2.10 & 0.40 & 27.69 & -0.24 & -1.03 & $0.11^{* *}$ \\
\hline${ }^{3} \mathrm{~W}_{1}(12 \mathrm{~h})$ & 1.70 & 1.70 & 0.40 & 3.10 & 0.57 & 33.42 & 0.15 & -0.61 & $0.08^{* *}$ \\
\hline${ }^{4} \mathrm{~W}_{2}(12 \mathrm{~h})$ & 1.12 & 1.08 & 0.47 & 1.96 & 0.38 & 33.91 & 0.23 & -0.99 & 0.09 ** \\
\hline${ }^{3} W_{1}(15 h)$ & 1.76 & 1.70 & 0.70 & 3.20 & 0.60 & 33.80 & 0.36 & -0.78 & $0.11^{\text {** }}$ \\
\hline${ }^{4} \mathrm{~W}_{2}(15 \mathrm{~h})$ & 1.56 & 1.40 & 0.50 & 3.10 & 0.70 & 44.92 & 0.58 & -0.72 & $0.11^{\star \star}$ \\
\hline \multicolumn{10}{|c|}{ Illuminance (lux) } \\
\hline $5 I_{1}(9 h)$ & 1650.00 & 900.00 & 250.00 & 4700.00 & 1288.00 & 78.02 & 0.82 & -0.76 & 0.22 ** \\
\hline${ }^{6} I_{2}(9 \mathrm{~h})$ & 591.10 & 367.00 & 100.00 & 2300.00 & 463.40 & 78.40 & 1.30 & 1.86 & $0.24^{* *}$ \\
\hline${ }^{5} I_{1}(12 h)$ & 1878.00 & 934.00 & 370.00 & 6500.00 & 1485.00 & 79.08 & 0.76 & -0.34 & $0.25^{\star \star}$ \\
\hline${ }^{6} I_{2}(12 h)$ & 1205.50 & 585.00 & 208.00 & 4563.00 & 966.70 & 80.19 & 0.83 & -0.11 & $0.26 * *$ \\
\hline $5 I_{1}(15 h)$ & 1074.70 & 702.00 & 100.00 & 3200.00 & 735.30 & 68.42 & 0.41 & -1.19 & 0.19 ** \\
\hline${ }^{6} I_{2}(15 h)$ & 927.50 & 612.00 & 144.00 & 2736.00 & 630.90 & 68.02 & 0.42 & -1.20 & 0.20 ** \\
\hline
\end{tabular}
fact occurs due to the high variability in the direction and magnitude of the natural winds, since aviary 1 had the curtains fully open and aviary 2 had partially open side curtains.

Queiroz et al. (2017) observed a medium CV in the morning and high CV in the afternoon for wind speed, under

Table 1. Descriptive statistics of temperature, wind speed and illuminance for aviaries without and with birds

${ }^{1} \mathrm{~T}_{1}$ : Temperature in aviary 1 (without birds); ${ }^{2} \mathrm{~T}_{2}$ : Temperature in aviary 2 (with birds); ${ }^{3} \mathrm{~W}_{1}$ : Wind speed in aviary $1 ;{ }^{4} \mathrm{~W}_{2}$ : Wind speed in aviary $2 ;{ }^{5} \mathrm{I}_{1}$ : Illuminance in aviary 1 ; ${ }^{6} \mathrm{I}_{2}$ : Illuminance in aviary 2; ${ }^{7}$ Min: Minimum; ${ }^{8}$ Max: Maximum; ${ }^{9} \mathrm{SD}$ : Standard Deviation; ${ }^{10} \mathrm{CV}$ : Coefficient of Variation; ${ }^{11}$ Sk: Skewness; ${ }^{12} \mathrm{Kt}$ : Kurtosis; ${ }^{13} \mathrm{KS}$ : Kolmogorov-Smirnov

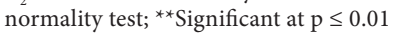


semi-arid condition and with the use of nebulizers. Aviary 2 had higher CV values in the afternoon, because in this period the curtains were up on the left side, to better control the incidence of illuminance within the installation, which led to high variability.

The CV values of illuminance were high, since they were all above $24 \%$. This variability can be explained by the orientation of the aviaries, which are longitudinally oriented in the Northwest-Southeast quadrant according to the compass rose in Figure 1B, which promoted the incidence of solar radiation on the floor, causing an increase in radiant thermal load in the aviaries. In addition, the high values of standard deviation and asymmetry in both facilities justify the high spatial variability of illuminance throughout the day.

The ranges obtained for air temperature in the facilities were high, considering the dimensions of the aviary (Table 2). This finding is an intrinsic characteristic of temperature, which according to Lopes et al. (2017) has generally strong continuity, with consequent continuous fields with high range, when spatial interpolation methods are used.

The variables wind speed and illuminance showed reduced ranges, between 5 and $10 \mathrm{~m}$ (Table 2). The spatial variability of the speed of natural winds does not provide internal continuity in both facilities, with partial dependence on the external environment. This variability is verified at all internal points of the structure. For illuminance, variability is provided by the direct incidence of sunlight on the floor.

The spatial variability of air temperature in both facilities is presented in the kriging maps, for the times of 9, 12 and $15 \mathrm{~h}$ (Figure 2). According to Furtado et al. (2003), a comfortable environment for birds should have temperatures between 22 and $27^{\circ} \mathrm{C}$. Temperatures outside this range cause thermal stress on the birds, as observed in the maps of Figure 2.

Figure $2 \mathrm{~B}$ shows that air temperature was within the comfort zone for the animals at $9 \mathrm{~h}$ in a small area of the aviary,
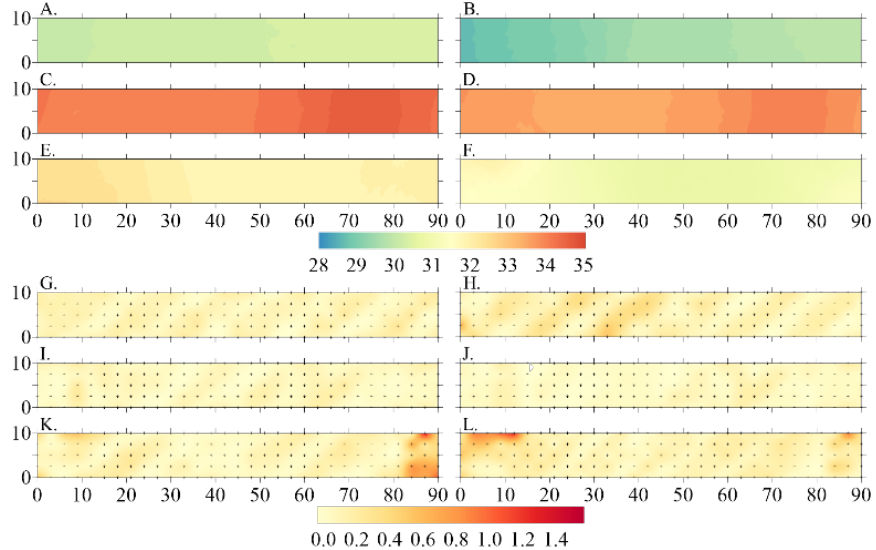

Figure 2. Spatial variability of temperature for (A) $9 \mathrm{~h}$ in aviary 1 (without birds), (B) $9 \mathrm{~h}$ in aviary 2 (with birds), (C) $12 \mathrm{~h}$ in aviary $1,(\mathrm{D}) 12 \mathrm{~h}$ in aviary 2 , (E) $15 \mathrm{~h}$ in aviary 1 , (F) $15 \mathrm{~h}$ in aviary 2 and their respective maximum residuals of kriging at the temperatures with and without birds ( $G, H, I, J, K$ and L), respectively

while in most of the structure the temperature exceeded $27^{\circ} \mathrm{C}$. In addition, the distribution of air temperature throughout the installation was heterogeneous, with higher values on the right side. However, it should be pointed out that the right side of the installation was the area with higher incidence of solar radiation (sunrise side), so at the beginning of the day, the temperatures were higher only on this side of the installation.

At 12 and $15 \mathrm{~h}$, the temperature was above $30{ }^{\circ} \mathrm{C}$ for both facilities. However, in aviaries 1 and 2 (Figures 2C, D, E and F) a condition of thermal stress can be noted, because some temperatures exceeded $27^{\circ} \mathrm{C}$ (Furtado et al., 2003; Nazareno et al., 2009).

With lower temperatures than those observed and, consequently, better thermal comfort, Curi et al. (2014) obtained satisfactory responses working with Dark House and

Table 2. Semivariogram model and degree of spatial dependence (DSD) for air temperature, wind speed and illuminance for aviaries without and with birds

\begin{tabular}{|c|c|c|c|c|c|c|c|c|c|}
\hline Variahles & Madel & $7 \mathrm{C}_{0}$ & ${ }^{8} \mathrm{C}+\mathrm{C}$ & $9 a$ & $10 R^{2}$ & $\mathbf{C}_{0} /\left(\mathbf{C}_{0}+\mathbf{C}\right)$ & 11Dsn & \multicolumn{2}{|c|}{ Jack-Knifing } \\
\hline Vantavits & movol & $v_{0}$ & 00 & $a$ & & (\%) & & Mean & ${ }^{12} \mathrm{SD}$ \\
\hline \multicolumn{10}{|c|}{ Temperature $\left({ }^{\circ} \mathrm{C}\right)$} \\
\hline${ }^{1} \mathrm{~T}_{1}(9 \mathrm{~h})$ & Gaussian & 0.01 & 0.07 & 114.52 & 0.84 & 14.28 & St & -0.010 & 0.941 \\
\hline${ }^{2} \mathrm{~T}_{2}(9 \mathrm{~h})$ & Gaussian & 0.01 & 0.68 & 89.98 & 0.97 & 1.47 & St & -0.017 & 1.332 \\
\hline${ }^{1} \mathrm{~T}_{1}(12 \mathrm{~h})$ & Gaussian & 0.01 & 0.11 & 55.46 & 0.91 & 9.09 & St & 0.001 & 0.708 \\
\hline${ }^{2} \mathrm{~T}_{2}(12 \mathrm{~h})$ & Gaussian & 0.01 & 0.08 & 48.22 & 0.91 & 12.50 & St & 0.000 & 0.653 \\
\hline${ }^{1} \mathrm{~T}_{1}(15 \mathrm{~h})$ & Gaussian & 0.03 & 0.18 & 64.58 & 0.83 & 16.66 & St & 0.001 & 0.859 \\
\hline${ }^{2} \mathrm{~T}_{2}(15 \mathrm{~h})$ & Gaussian & 0.06 & 0.32 & 62.89 & 0.78 & 18.75 & St & -0.012 & 0.675 \\
\hline \multicolumn{10}{|c|}{ Wind speed $\left(\mathrm{m} \mathrm{s}^{-1}\right)$} \\
\hline${ }^{3} W_{1}(9 h)$ & Spherical & 0.001 & 0.39 & 6.64 & 0.80 & 0.25 & St & 0.006 & 0.763 \\
\hline${ }^{4} W_{2}(9 h)$ & Spherical & 0.001 & 0.15 & 6.16 & 0.68 & 0.66 & St & -0.012 & 0.819 \\
\hline${ }^{3} \mathrm{~W}_{1}(12 \mathrm{~h})$ & Spherical & 0.001 & 0.31 & 7.96 & 0.71 & 0.32 & St & 0.046 & 0.609 \\
\hline${ }^{4} W_{2}(12 h)$ & Spherical & 0.001 & 0.13 & 7.47 & 0.73 & 0.76 & St & 0.039 & 0.642 \\
\hline${ }^{3} W_{1}(15 h)$ & Spherical & 0.001 & 0.38 & 8.35 & 0.86 & 0.26 & St & 0.046 & 0.702 \\
\hline${ }^{4} \mathrm{~W}_{2}(15 \mathrm{~h})$ & Spherical & 0.001 & 0.52 & 9.89 & 0.91 & 0.19 & St & 0.058 & 0.625 \\
\hline \multicolumn{10}{|c|}{ Illuminance (lux) } \\
\hline$\left.5\right|_{1}(9 h)$ & Gaussian & 1000 & 1682000 & 6.59 & 0.96 & 0.05 & St & -0.043 & 0.830 \\
\hline${ }^{6} \mathrm{I}_{2}(9 \mathrm{~h})$ & Gaussian & 1000 & 1135000 & 7.48 & 0.89 & 0.08 & St & -0.010 & 0.450 \\
\hline${ }^{5} I_{1}(12 h)$ & Gaussian & 1000 & 2255000 & 6.21 & 0.84 & 0.04 & St & -0.030 & 0.391 \\
\hline${ }^{6} I_{2}(12 h)$ & Gaussian & 1000 & 884000 & 6.11 & 0.87 & 0.11 & St & -0.073 & 1.195 \\
\hline $5 I_{1}(15 h)$ & Gaussian & 1000 & 521500 & 5.66 & 0.78 & 0.19 & St & -0.037 & 0.675 \\
\hline $6 I_{2}(15 \mathrm{~h})$ & Gaussian & 1000 & 383600 & 5.71 & 0.79 & 0.26 & St & -0.034 & 0.647 \\
\hline
\end{tabular}

${ }^{1} \mathrm{~T}_{1}$ : Temperature in aviary 1 (without birds); ${ }^{2} \mathrm{~T}_{2}$ : Temperature in aviary 2 (with birds); ${ }^{3} \mathrm{~W}_{1}$ : Wind speed in aviary $1 ;{ }^{4} \mathrm{~W}_{2}$ : Wind speed in aviary $2 ;{ }^{5} \mathrm{I}_{1}:$ Illuminance in aviary $1 ;$

${ }^{6} \mathrm{I}_{2}$ : Illuminance in aviary $2 ;{ }^{7} \mathrm{C}_{0}$ : Nugget effect; ${ }^{8} \mathrm{C}_{0}+\mathrm{C}$ : Sill; ${ }^{9}$ a: Range; ${ }^{10} \mathrm{R}^{2}$ : Fit of the semivariogram; ${ }^{11} \mathrm{DSD}$ : degree of spatial dependence (\%); ${ }^{12} \mathrm{SD}$ : Standard deviation; St: Strong 
Solid Wall aviaries, in which the air temperatures of 26.73 and $25.45^{\circ} \mathrm{C}$, respectively, provided thermal comfort for the birds.

The time that provided greater uniformity of air temperature in the facilities was $12 \mathrm{~h}$, because the solar incidence was uniform throughout the roof and did not hit the floor directly. This can also be observed in Figures 2I and J, in which kriging residuals were lower for aviaries 1 and 2, explained by the absence of temperature variations in the entire aviary.

Aviary 2 had temperatures close to those of aviary 1, despite having an air conditioning system. This was due to the exchange of heat between the birds and the environment, with positive energy balance, which led to an increase in air temperature, probably due to the dissipation by radiation from the birds. It is worth mentioning that the air conditioning system worked intermittently, so it is necessary to adjust its programming base in order to provide temperatures closer to the comfort zone of the birds.

It was observed that the wind speed at $9 \mathrm{~h}$ ranged from 0.60 to $3.80 \mathrm{~m} \mathrm{~s}^{-1}$ and from 0.50 to $2.10 \mathrm{~m} \mathrm{~s}^{-1}$ for aviaries 1 and 2, respectively (Figure 3 ). However, there was a greater predominance of velocity around $1.5 \mathrm{~m} \mathrm{~s}^{-1}$ inside the aviaries. Medeiros et al. (2005) state that the ideal wind speed within a poultry installation should initially be $1.5 \mathrm{~m} \mathrm{~s}^{-1}$, reaching $3.5 \mathrm{~m} \mathrm{~s}^{-1}$ at the end of the cycle.

Bustamante et al. (2017) observed values close to $1.5 \mathrm{~m} \mathrm{~s}^{-1}$ in a broiler house in Spain with similar dimensions, but with constant forced ventilation. However, the authors emphasized that the highest ventilation rates $\left(\mathrm{V}>1.5 \mathrm{~m} \mathrm{~s}^{-1}\right)$ at certain points in the facilities were not adequate for the birds. Carvalho et al. (2012) found maximum velocity values of $0.75 \mathrm{~m} \mathrm{~s}^{-1}$, so it was necessary to intensify the air speed in the facilities.

It was observed that the facilities need adjustments in the wind speed at certain points. In Figures $3 \mathrm{~A}, \mathrm{C}$ and E (9, 12 and $15 \mathrm{~h}$, respectively), the wind speed at the ends of the installation of aviary 1 is above $1.5 \mathrm{~m} \mathrm{~s}^{-1}$ and in the center it is below this value, as observed by Bustamante et al. (2017). Through the kriging residual maps of Figure $3 \mathrm{G}$, I and K, it was found that the residuals were low for these cases. The same situation can be observed for aviary 2 in Figures 3B, D
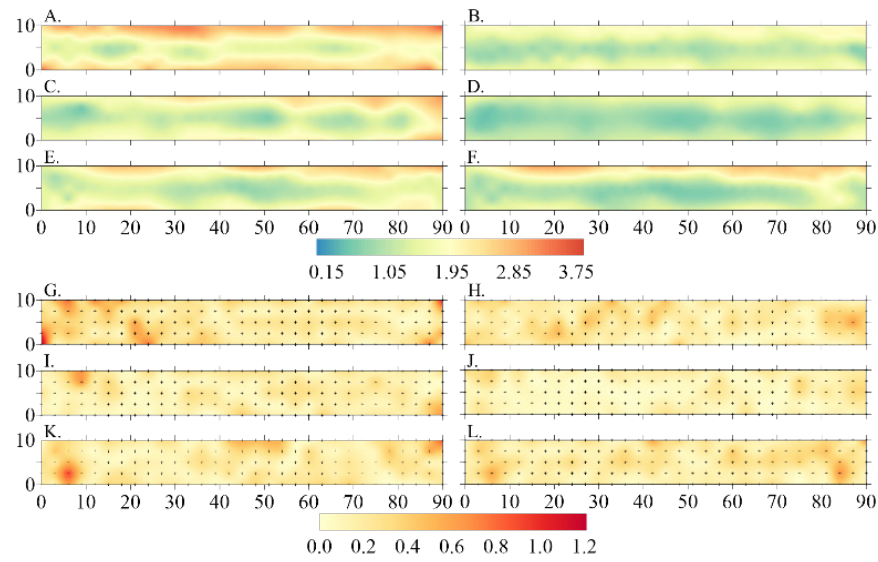

Figure 3. Spatial variability of wind speed for (A) $9 \mathrm{~h}$ in aviary 1 (without birds), (B) $9 \mathrm{~h}$ in aviary 2 (with birds), (C) $12 \mathrm{~h}$ in aviary 1, (D) $12 \mathrm{~h}$ in aviary 2, (E) $15 \mathrm{~h}$ in aviary $1,(\mathrm{~F}) 15 \mathrm{~h}$ in aviary 2 and their respective maximum residuals of kriging at the wind speed without $(G, I, K)$ and with birds $(H, J, L)$, respectively and $\mathrm{F}$, in which the kriging residuals observed in Figures $3 \mathrm{H}$, $\mathrm{J}$ and $\mathrm{L}$ were also low.

This fact occurs because the birds block part of the incident wind within aviary 2 , thus causing lower wind speeds in the center. Longer use of fans is a possible solution to this problem.

For aviary 1, as observed in Figures 4A, C and E (9, 12 and $15 \mathrm{~h}$ ), the values of illuminance at all times were above the ideal range of comfort for the animals, from 5 to 20 lux (Santana et al., 2014). This occurs because the installation is fully open throughout the day, and therefore the incidence of light was higher. Jones et al. (2005) and Lin et al. (2006) establish the following ranges for illuminance: lux of 0-9 is considered low, $10-99$ is considered medium and 100 is considered high.

Aviary 2 (Figures 4B, D and F) at 9, 12 and $15 \mathrm{~h}$ had lower illuminance, which was associated with the use of curtains. However, it was still above the comfort range for the animals according to Lin et al. (2006), who establish that the maximum value allowed for birds is $100 \mathrm{~lx}$.

The use of natural lighting, despite its variation during the day, promotes lower consumption of electricity, and it is up to the producer to perform the management of closing and opening of the side curtains to adapt the illuminance inside the aviary. Ribeiro et al. (2016) observed lux values higher than 100, even with artificial lighting in the southern region of Minas Gerais, Brazil. Another possible alternative would be the use of a device that reduces the intensity of the electrical current of the lighting system (dimmer), which would enable the control of illuminance within the recommended range from 5 to 20 lux (Santana et al., 2014).

It was observed that aviary 2 had lower illuminance when compared to aviary 1 , due to the management of side curtains to control the entry of air and light.
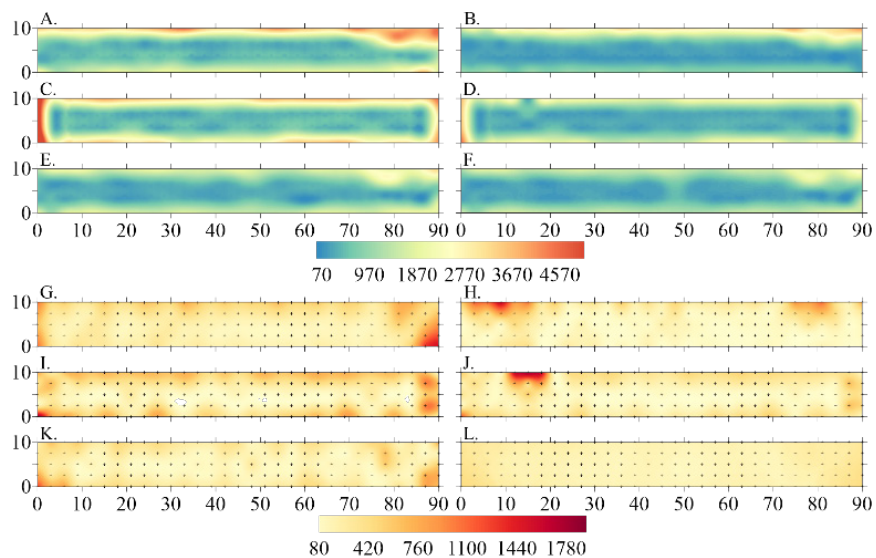

Figure 4. Spatial variability of illuminance for (A) $9 \mathrm{~h}$ in aviary 1 (without birds), (B) $9 \mathrm{~h}$ in aviary 2 (with birds), (C) $12 \mathrm{~h}$ in aviary 1, (D) $12 \mathrm{~h}$ in aviary 2, (E) $15 \mathrm{~h}$ in aviary $1,(\mathrm{~F}) 15 \mathrm{~h}$ in aviary 2 and their respective maximum residuals of kriging without $(\mathrm{G}, \mathrm{I}, \mathrm{K})$ and with birds $(\mathrm{H}, \mathrm{J}, \mathrm{L})$, respectively

\section{Conclusions}

1. There is strong spatial dependence for the variables air temperature, wind speed and illuminance in aviaries without and with birds.

2. The ranges obtained for air temperature in the aviaries were from 48.22 to $114.52 \mathrm{~m}$, while for wind speed and illuminance the ranges were less than $10 \mathrm{~m}$. 


\section{Literature Cited}

Bustamante, E.; Calvet, S.; Estellés, F.; Torres, A. G.; Hospitaler, A. Measurement and numerical simulation of single-sided mechanical ventilation in broiler houses. Biosystems Engineering, v.160, p.5568, 2017. https://doi.org/10.1016/j.biosystemseng.2017.05.009

Cambardella, C. A.; Moorman, T. B.; Novak, J. M.; Parkin, T. B.; Karlen, D. L.; Turco, R. F.; Konopka, A. E. Field-scale variability of soil properties in central Iowa soils. Soil Science Society America Journal, v.58, p.1501-1511, 1994. https://doi.org/10.2136/ sssaj1994.03615995005800050033x

Carvalho, T. M. R. de; Moura, D. J. de; Souza, Z. M. de; Souza, G. S. de; Bueno, L. G. de F. Qualidade da cama e do ar em diferentes condições de alojamento de frangos de corte. Pesquisa Agropecuária Brasileira, v.46, p.351-361, 2011. https://doi. org/10.12702/II-SGEA-a43

Carvalho, T. M. R. de; Moura, D. J. de; Souza, Z. M. de; Souza, G. S. de; Bueno, L. G. de F.; Lima, K. A. O. de. Use of geostatistics on broiler production for evaluation of different minimum ventilation systems during brooding phase. Revista Brasileira de Zootecnia, v.41, p.194-202, 2012. http://dx.doi.org/10.1590/ S1516-35982012000100028

Curi, T. M. R. C.; Vercellino, R. A.; Massari, J. M.; Souza, Z. M.; Moura, D. J. de. Geoestatística para avaliação do controle ambiental do sistema de ventilação em instalações comerciais para frangos de corte. Engenharia Agrícola, v.34, p. 1062-1074, 2014. http://dx.doi. org/10.1590/S0100-69162014000600004

Deutsch, C. V.; Journel, A. G. GSLIB Geostatistical software library and user's guide. 2.ed., New York: Oxford University Press, 1998. $369 \mathrm{p}$.

Englund, E. J.; Sparks, A. Geo-EAS (Geostatistical Environmental Assessment Software). Users's guide. Las Vegas: U.S. Environmental Monitoring Systems Laboratory, 1989. 170p. EPA/600/4-88/033a. https://doi.org/10.1016/0266-9838(89)90033-6

Faria, F. F.; Moura, D. J.; Souza, Z. M.; Matarazzo, S. V. Variabilidade espacial do microclima de um galpão utilizado para confinamento de bovinos de leite. Ciência Rural, v.38, p.2498-2505, 2008. http:// dx.doi.org/10.1590/S0103-84782008000900013

Furtado, D. A.; Azevedo, P. V.; Tinôco, I. F. F. Análise do conforto térmico em galpões avícolas com diferentes sistemas de acondicionamento. Revista Brasileira de Engenharia Agrícola e Ambiental, v.7, p.559-564, 2003. https://doi.org/10.1590/S141543662003000300025

Golden Software. Surfer for windows version 9.0. Colorado: Golden, 2010.66p.

Gonçalves, I.; Turco, S. H. N.; Ramos, C. M. C. Spatial variability of air temperature in a free-stall in the Northeastern semi-arid region of Brazil. Revista Brasileira de Engenharia Agrícola e Ambiental, v.20, p.67-71, 2016. http://dx.doi.org/10.1590/18071929/agriambi.v20n1p67-71

Jones, E. K. M.; Wathes, C. M.; Webster, A. J. F. Avoidance of atmospheric ammonia by domestic fowl and the effect of early experience. Applied Animal Behaviour Science, v.90, n.3, p.293308, 2005. https://doi.org/10.1016/j.applanim.2004.08.009
Lin, H.; Jiao, H. C.; Buyse, J.; Decuypere, F. Strategies for preventing heat stress in poultry. World's Poultry Journal, Beekbergen, v.62, p.71-85, 2006. https://doi.org/10.1079/WPS200585

Lopes, I.; Melo, J. M. M.; Leal, B. G. Espacialização da temperatura do ar para a região do Submédio São Francisco. Irriga, v.22, p.177193, 2017. https://doi.org/10.15809/irriga.2017v22n1p177-193

Medeiros, B. B. L.; Moura, D. J. de; Massari, J. M.; Curi, T. M. R. de C.; Maia, A. P. de A. Uso da geoestatística na avaliação de variáveis ambientais em galpão de suínos criados em sistema "wean to finish" na fase de terminação. Engenharia Agrícola, v.34, p.800811, 2014. http://dx.doi.org/10.1590/S0100-69162014000500001

Medeiros, C. M.; Baêta, F. C.; Oliveira, R. F. M.; Tinôco, I. F. F.; Albino, L. F. T.; Cecon, P. R. Índice térmico ambiental de produtividade para frangos de corte. Revista Brasileira de Engenharia Agrícola e Ambiental, v.9, p.660-665, 2005. http://dx.doi.org/10.1590/ S1415-43662005000400033

Nazareno, A. C.; Pandorfi, H.; Almeida, G. L. P.; Giongo, P. R.; Pedrosa, E. M. R.; Guiselini, C. Avaliação do conforto térmico e desempenho de frangos de corte sob regime de criação diferenciado. Revista Brasileira de Engenharia Agrícola e Ambiental, v.13, p.802-808, 2009. http://dx.doi.org/10.1590/ S1415-43662009000600020

Queiroz, M. L. V.; Barbosa Filho, J. A. D.; Sales, F. A. de L.; Lima, L. R. de; Duarte, L. M. Variabilidade espacial do ambiente em galpões de frango de corte com sistema de nebulização. Revista Ciência Agronômica, v.48, p.586-595, 2017.

Ribeiro, P. A. P.; Yanagi Junior, T.; Oliveira, D. D. D.; Ferraz, G. A. E. S.; Lourenconi, D. Spatial illuminances variability and energy consumption in aviaries for laying hens equipped with compact fluorescent lamps and light emitting diode. Engenharia Agrícola, v.36, p.962-971, 2016. http://dx.doi.org/10.1590/1809-4430-Eng. Agric.v36n6p962-971/2016

Santana, M. R.; Garcia, R. G.; Naas, I. A.; Paz, I. C. L. A.; Caldara, F. R.; Barreto, B. Light emitting diode (led) use in artificial lighting for broiler chicken production. Engenharia Agrícola, v.34, p.422427, 2014. https://doi.org/10.1590/S0100-69162014000300005

Vauclin, M.; Vieira, S. R.; Vachaud, G.; Nielsen, D. R. The use of cokriging with limited field soil observations 1 . Soil Science Society of America Journal, v. 47, n. 2, p. 175-184, 1983. 10.2136/ sssaj1983.03615995004700020001x

Wang, K.; Feng, G.; Ye, T.; Wang, X.; Liu, P. The variation characteristics of Asian surface temperature and precipitation in the early $21^{\text {st }}$ century. Discrete Dynamics in Nature and Society, v.2016, p.1-7, 2016. http://dx.doi.org/10.1155/2016/7929647

Warrick, A. W.; Nielsen, D. R. Spatial variability of soil physical properties in the field. In: Hillel, D. (Ed.). Applications of soil physics. New York: Academic, 1980. Cap. 2, p. 319-344. https:// doi.org/10.1016/B978-0-12-348580-9.50018-3

Yang, Y.; Yang, X.; Wang, X.; Li, J. Huaihua automatic weather station and manual observation contrastive analysis of meteorological elements. Journal of Chengdu University of Information Technology, v.1, 2012. 